EESTI NSV TEADUSTE AKADEEMIA TOIMETISED. XVIII KOIDE

KEEMIA * GEOLOOGIA, 1969, Nr. 2

ИЗВЕСТИЯ АКАДЕМИИ НАУК ЭСТОНСКОИ ССР. ТОМ ХVIII Химия * ГЕология. 1969, № 2

\title{
ОБ АБСОЛЮТНОМ ВОЗРАСТЕ ГОЛОЦЕНОВЫХ ТРАНСГРЕССИИ БАЛТИКИ НА ТЕРРИТОРИИ ЭСТОНИИ
}

Наряду с геоморфологическими, литологическими и биостратиграфическими методами в создании хрснологической шкалы голоценовых трансгрессий Балтийского моря на территории Эстонии в последние годы применяется радиоуглеродный метод определения абсолютного возраста.

Определение абсолютного возраста погребенных континентальных отложений под прнбрежными отложениями Балтикн, к сожалению, позволяет установить только приблизительный возраст морских трансгрессий, так как верхние слои погребенных лагунных и торфяных отложений часто абрадированы и имеют признаки перемешивания.

Материалы для определения абсолютного возраста и для спорово-пыльцевого анализа отбирались вручную из природных обнажений, кроме образцов из погребенных органогенных отложений Васькряэма, которые брались из шурфа.

При взятии образцов стенки обнажений очищались на ширину $1-2$ м. После детального визуального осмотра и описания очищенного обнажения отбирались образцы с соблюдением всех правил отбора их для радиоуглеродного датирования. По всему разрезу погребенных органогенных отложений послойно отбирались прямоугольные куски материала толщиной 3 см. Из середины каждого куска вырезались для споровопыльцевого анализа пробы толщиной $1-1,5 \mathrm{~cm}$.

Спорово-пыльцевой анализ выполнен Х. Кессел в Институте геологии АН Эстонской ССР на образцах, взятых через каждые 3 см по всему разрезу. Абсолютный возраст образцов определен радиоуглеродным методом в лаборатории геобиохимии Института зоологии и ботаники АН Эстонской ССР, в основном Я.-М. Пуннингом. ДатироЕаны образцы из верхних и нижних слоев оргакогенных отложений, а также образцы c ғазбором, например на уровнях, характеризующих появление диатомовых.

Перед датированием из образцов удалялись механические, карбонатные и гумусовые примеси (Пуннинг и др., 1966а). В качестве носителя природного $\mathrm{C}^{14}$ из предварительно обработанных и обугленных образцов синтезнровался бензол (Пуннинг и др., 1966б). Современный бензол был синтезирован из древесины возрастом $1870 \pm 10$ лег. Все радиоуглеродные датировки рассчитаны исходя из значения периода полураспада $\mathrm{C}^{14}$, равного $5568 \pm 30$ годам. За начало отсчета принят 1950 год.

Для установления эхенейсовой и анциловой трансгрессий изучались погребенные органогенные отложения шести разрезов (рис.1).

В местонахождении Тапу (юго-западная часть Эстонии) органогенные осадки (внизу древесный торф, вверху глинистый сапропель) мощностью около 55 см покрыты отложениями косы мощностью 2,5 $\mu$; в местонахождении Алтк юл а эти осадки покрыты прибрежными глинисто-алевритистыми отложениями мощностью 1,2 м. Предполагаемый 


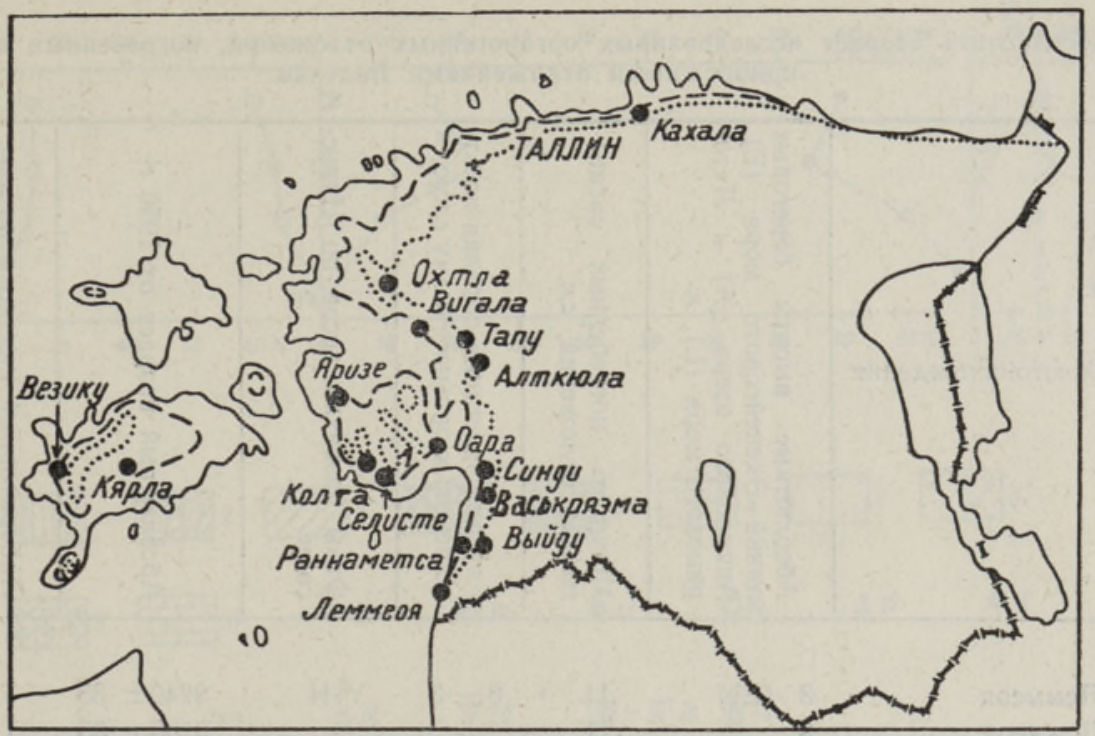

Рис. 1. Местонахождения погребенных органогенных отложений, возраст которых определен по $\mathrm{C}^{14}$ : _.. - береговая линия Литоринового моря, .... береговая линия Анцилового озера,

возраст древесного торфа в разрезе Тапу по спорово-пыльцевым данным - VIII фаза развития лесов (Кессел, 1963а). Преобладает пыльца сосны (до $79 \%$ ). Органогенные отложения из местонахождения Алткюла палинологически не изучены.

Абсолютный возраст погребенных органогенных отложений в Тапу и Алткюла соответственно $8995 \pm 125$ и $8460 \pm 180$ лет (таблица, п. 4 и 7).

В юго-западной части Эстонии изучались еще погребенные под трансгрессивными прибрежными осадками органогенные отложения на берегу ручья Л ем м е я и в стенках Тимм-канала у с. В ы йд у. Мощность подстилаемых гравием гипнового и древесного торфа в Леммеоя 12 см. По спорово-пыльцевым данным возраст этих отложений датируется VIII фазой развития лесов (рис. 2). Содержание пыльцы сосны $73-99 \%$. Абсолютный возраст погребенного древесного торфа по $\mathrm{C}^{14} 9240 \pm 85$ лет и древесины из слоя этого же торфа $9100 \pm 85$ лет (таблица, п. 1, 2). Органогенные отложения (гипновый и древесно-тростниковый торф) мощностью 17 см у с. Выйду залегают на морене. По спорово-пыльцевому анализу их предполагаемый возраст - VIII фаза развития лесов (Кессел, 1963б). Абсолютный возраст древесно-тростникового торфа $9100 \pm 90$ лет (таблица, п. 3).

В Северной Эстонии определен абсолютный возраст погребенных под анциловыми осадками органогенных отложений близ оз. Кахала и в c. Охтла. Мощность погребенного под мелкозернистыми лагунными песками гипнового торфа в Кахала - 55 см. Как показывает споровопыльцевая диаграмма, в торфе содержится много пыльцы березы (до $79 \%$ ) и мало пыльцы ольхи и сосны (рис. 3). Органогенные отложения из местонахождения Охтла палинологически не изучены. Абсолютный возраст торфа в Кахала и Охтла по С ${ }^{14}$ соответственно $8595 \pm 75$ и $8560 \pm$ \pm 110 лет (таблица, п. 5 и 6 ). 
Абсолютный возраст исследованных органогенных отложений, погребенных под прибрежными отложениями Балтики

\begin{tabular}{|c|c|c|c|c|c|c|c|}
\hline $\begin{array}{l}\text { 吉 } \\
\text { 先 }\end{array}$ & Местонахождения & 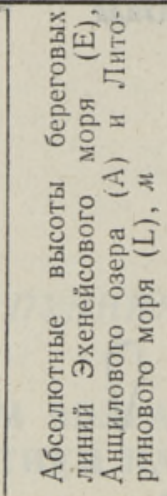 & 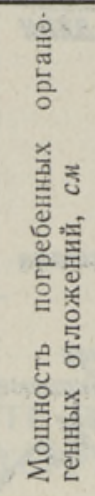 & 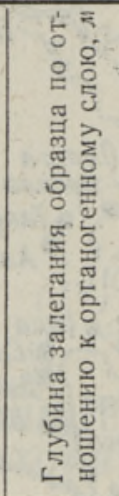 & 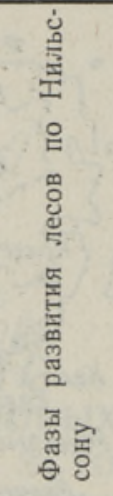 & 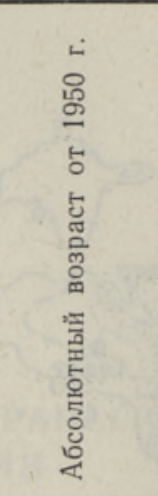 & 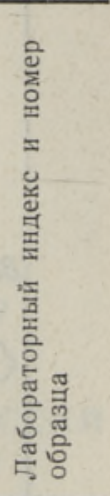 \\
\hline 1. & Леммеоя & 3 (E?) & 11 & $0-3$ & VIII & $9240 \pm 85$ & TA-122 \\
\hline 2. & Леммеоя & 3 & 11 & 5 & - & $9100 \pm 85$ & TA-123 \\
\hline 3. & Выйду & 8 (E?) & 13 & $5-13$ & VIII & $9100 \pm 125$ & TA-77 \\
\hline 4. & Tany (Пяэрду) & 21,5 (E?) & 54 & $50-54$ & VIII & $8995 \pm 125$ & TA-78 \\
\hline 5. & Кахала & $32\left(\mathrm{~A}_{\mathrm{I}}\right)$ & 30 & $0-10$ & VIII & $8595 \pm 75$ & TA-59 \\
\hline 6. & Охтла & $33 \quad\left(A_{I}\right)$ & 17 & $5-15$ & - & $8560 \pm 110$ & TA-195 \\
\hline 7. & Алткюла & $20,5\left(A_{I}\right)$ & 15 & $5-15$ & - & $8460 \pm 180$ & TA-75 \\
\hline 8. & Везику & $17\left(\mathrm{~L}_{\mathrm{II}}\right)$ & 39 & $33-36$ & VII & $7960 \pm 80$ & TA- 179 \\
\hline 9. & Раннаметса & $6,5\left(L_{11}\right)$ & 30 & $24-30$ & VII & $7860 \pm 190$ & TA-54 \\
\hline 10. & Кярла & $17\left(\mathrm{~L}_{\mathrm{II}}\right)$ & 36 & $30-33$ & VII & $7820 \pm 80$ & TA-182 \\
\hline 11. & Васькряэма & $8,5\left(\mathrm{~L}_{\mathrm{II}}\right)$ & 40 & $35-40$ & VII & $7580 \pm 170$ & TA-140 \\
\hline 12. & Кольга & $12\left(\mathrm{~L}_{\mathrm{II}}\right)$ & 18 & $0-3$ & VI & $7505 \pm 165$ & TA-126 \\
\hline 13. & Вигала & $15\left(\mathrm{~L}_{\mathrm{II}}\right)$ & 35 & $25-35$ & - & $7375 \pm 70$ & TA- 157 \\
\hline 14. & Кярла & $17\left(\mathrm{~L}_{\mathrm{II}}\right)$ & 36 & $0-3$ & VI & $7085 \pm 80$ & TA-181 \\
\hline 15. & Васькряэма & $8,5\left(\mathrm{~L}_{\mathrm{II}}\right)$ & 40 & $15-18$ & VI & $6975 \pm 110$ & TA-141 \\
\hline 16. & Яризе & $18\left(\mathrm{~L}_{\mathrm{II}}\right)$ & 20 & $10-20$ & - & $6960 \pm 170$ & TA-198 \\
\hline 17. & Васькряэма & $8,5\left(\mathrm{~L}_{\mathrm{II}}\right)$ & 40 & $5-10$ & - & $6870 \pm 110$ & TA-139 \\
\hline 18. & Синди & $9 \quad\left(\mathrm{~L}_{\mathrm{II}}\right)$ & 130 & $25-32$ & - & $6710 \pm 110$ & TA-55 \\
\hline 19. & Везику & $17\left(\mathrm{~L}_{\mathrm{II}}\right)$ & 39 & $0-3$ & VI & $6350 \pm 80$ & TA-178 \\
\hline 20. & Oapa & $8,5\left(\mathrm{~L}_{\mathrm{II}}\right)$ & 133 & $0-3$ & VI & $6100 \pm 50$ & TA-193 \\
\hline 21. & Селисте & $11\left(\mathrm{~L}_{\mathrm{II}}\right)$ & 52 & $3-8$ & V & $5950 \pm 60$ & TA-183 \\
\hline
\end{tabular}

Сравним полученные нами датировки с новейшими данными определения абсолютного возраста анциловой трансгрессии в Швеции (Lundqvist, 1965a). Образец торфа из-под анцилового берегового вала около Фрейеля (юго-залад о-ва Готланд) датируется возрастом $9155 \pm 135$ лет и по спорово-пыльцевым данным относится к VIII фазе развития лесов (пыльца сосны $90 \%$ ). Возраст этого торфа хорошо коррелируется с возрастом погребенных отложений в Тапу, Выйду и Леммеоя.

Погребенные органогенные отложения из-под анцилового вала около Сяллмура и Мальмса (юго-запад и северо-восток о-ва Готланд) оказались более молодыми: соответственно $8480 \pm 100$ и $8410 \pm 145$ лет и хорошо согласуются по возрасту с погребенными отложениями в Кахала, Алткюла и Охтла.

Как показывают спорово-пыльцевые данные, органогенные отложения в Сяллмуре и Мальмсе относятся также к VIII фазе развития лесов, 

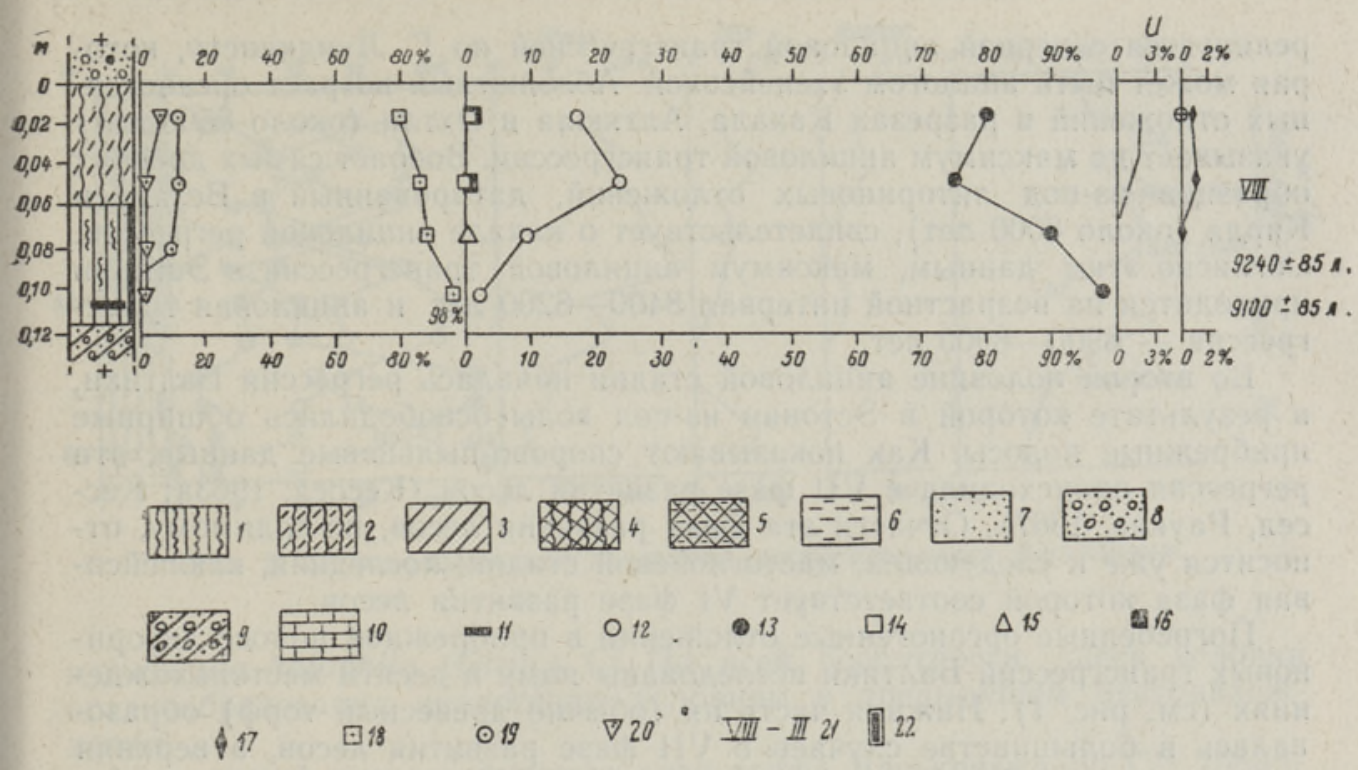

Рис. 2. Спорово-пыльцевая диаграмма местонахождения Леммеоя.

Усдовные обозначения к рис. $2-5$ и $7-10: I-$ древесный торф с остатками тростника; 2 - тростниково-гипновый торф: 3 - осоковый торф; 4 - сапропель, содержащий в большом количестве остаткн тростника; 5 - глиннстый сапропель; 6 - глина; 7 - песок: 8- прибрежные отложения; 9 морена; 10 - коренные породы; 11 - кускн древесины; 12 - береза; 13 - сосна; $14-$ ольха, 15 - ель; 16 - сумма пыльцы широколиственных пород; 17 - орешник; 18 - пыльца древесных пород н кустарннков; 19 - пыльца травянистых растений; 20 - споры; 21 - фазы развития лесов пород и кустарников; 19 - пыльца травянистых растений; $20-$ споры; 21 - фазы развития лесов
по Нильссону (Nilsson, 1935); 22 - уровни, откуда взяты образцы для определения абс. возпо Нильссону (Nilsson, 1935); $22-$ ровн, отка по $\mathrm{C}^{14}$.

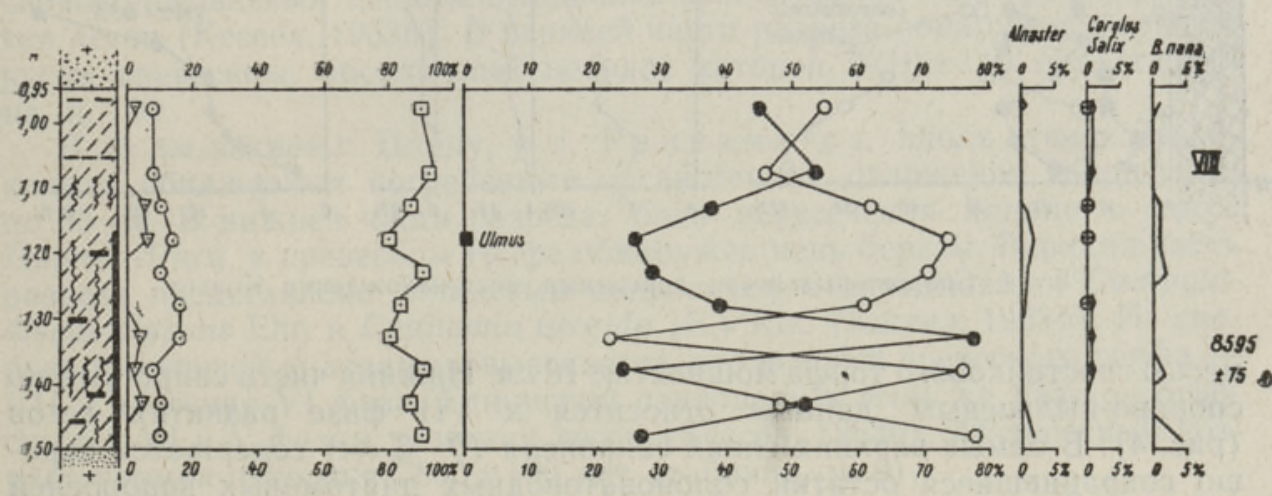

Рис. 3 Спорово-пыльцевая диаграмма местонахождения Кахала.

но для них характерно повышенное содержание пыльцы березы (до $50 \%$ ). То же самое наблюдается и на спорово-пыльцевой диаграмме Кахала (Северная Эстония).

На основании приведенных датировок Г. Лундквиста (Lundqvist, 1965a) на о-ве Готланд установлены две анциловые трансгрессии.

Мы полагаем, что погребенные в начале VIII фазы развития лесов

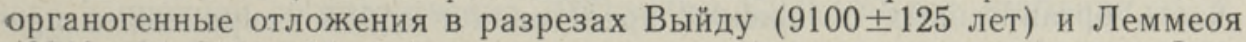
$(9240 \pm 85,9100 \pm 85$ лет) залегают под прибрежными отложениями Эхенейсового моря. Поскольку на местонахождении Леммеоя определен самый верхний слой торфа, а в Тапу (8995 125 лет) - самый нижний, то максимум эхенейсовой трансгрессии в.Эстонии можно датировать янтервалом от 9200 до 9000 лет. Возраст этой трансгрессии хорошо кор- 
релируется с первой анциловой трансгрессией по Г. Лундквисту, которая может быть аналогом эхенейсовой. Абсолютный возраст органогенных отложений в разрезах Кахала, Алткюла и Охтла (около 8500 лет) указывает на максимум анциловой трансгрессии. Возраст самых древних образцов из-под литориновых отложений, датированный в Везику и Кярла (около 8000 лет), свидетельствует о начале анциловой регрессии. Согласно этим данным, максимум анциловой трансгрессии в Эстонии приходится на возрастной интервал $8400-8200$ лет и анциловая трансгрессия - 8900-8000 лет.

Во второй половине анциловой стадии началась регрессия Балтики, в результате которой в Эстонии из-под воды освободились обширные прибрежные полосы. Как показывают спорово-пыльцевые данные, эта регрессия происходила в VII фазе развития лесов (Кессел, 1963a; Кессел, Раукас, 1967). Отчасти эта фаза развития лесов, по-видимому, относится уже к следующей, мастоглойевой стадии, последняя, клюпейсовая фаза которой соответствует VI фазе развития лесов.

Погребенные органогенные отложения в прибрежной полосе литориновых трансгрессий Балтики исследованы нами в десяти местонахождениях (см. рис. 1). Нижняя часть их (обычно древесный торф) образовалась в большинстве случаев в VII фазе развития лесов, а верхняя (обычно лагунный сапропель) - в VI фазе и в одном случае, по-видимому, в V фазе развития лесов (таблица, п. 8-21).

В обнажении на берегу ручья Коль га (близ пос. Тыстамаа в ЮгоЗападной Эстонии) под пятиметровыми отложениями берегового бара Питоринового моря и прибрежными дюнами залегает сапропель с прн-
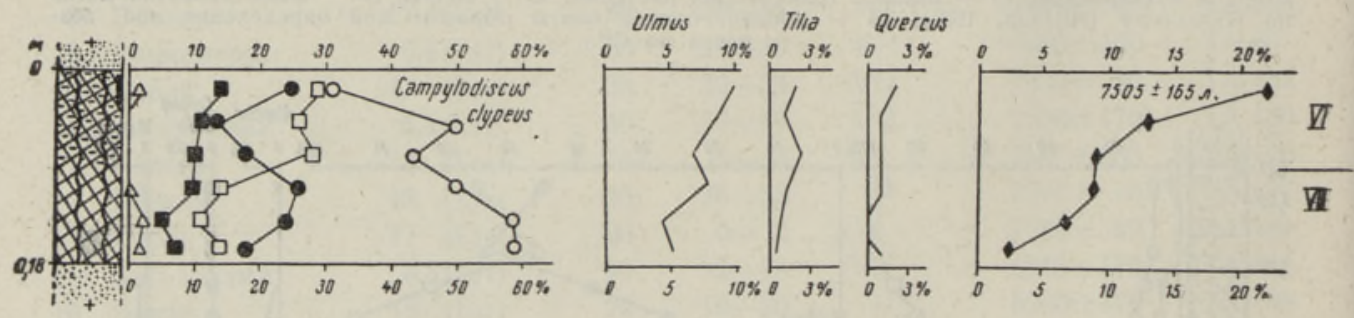

Рис 4. Спорово-пыльцевая диаграмма местонахождения Кольга.

месью тростникового торфа мощностью $18 \mathrm{~cm}$. Нижняя часть сапропеля по спорово-пыльцевым данным относится к VII фазе развития лесов (рис. 4). В самых верхних слоях сапропеля (0-3 cм) содержатся хорошо сохранившиеся остатки солоноватоводных диатомовых водорослей Campylodiscus clypeus Ehr. и Mastogloia Braunii Grun. Возраст этой части сапропеля соответствует VI фазе развития лесов. Характер органогенных отложений и особенности геоморфологии прибрежных форм рельефа явно свидетельствует о накоплении верхних слоев сапропеля в лагуне. Абсолютный возраст упомянутых самых верхних слоев по радиоуглероду $7505 \pm 165$ лет (таблица, п. 12).

Погребенные органогенные отложения в В аськряэма (в $0,5 \kappa м$ западнее одноименной ж-д. станции) имеют мощность 47 см. Верхняя часть органогенных отложений представляет собой сапропель с примесью тростникового торфа, нижняя часть - древесный торф. Согласно спорово-пыльцевым данным, древесный торф относится к VII фазе, а сапропель - к VI фазе развития лесов (рис. 5).

В верхней части лагунного сапропеля Васькряэма содержатся остатки солоноватоводных диатомовых водорослей Campylodiscus clypeus Ehr. 


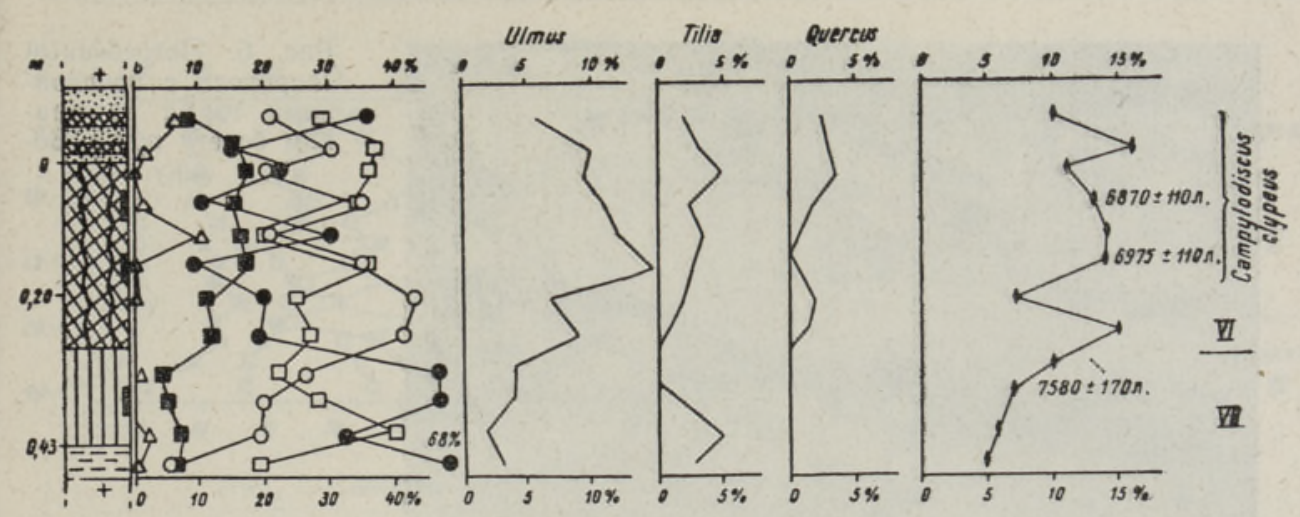

Рис. 5. Спорово-пыльцевая диаграмма местонахождения Васькряэма.

и Navicula halophila (Grun.) Cl. По всей вероятности, здесь условия осадкообразования аналогичны условиям в предыдущем местонахождении,

Абсолютный возраст нижнего слоя торфа Васькряэма по С $147580 \pm$ \pm 170 лет, слоев сапропеля, характеризующихся появлением солоноватоводных водорослей, $6975 \pm 110$ и самого верхнего слоя сапропеля $6780 \pm$ \pm 110 лет (таблица, п. 11,15 и 17).

В $5 \kappa м$ к юго-востоку от г. Пярну, близ г. С инд и, на левом берегу p. Пярну под прибрежными песками литориновой трансгрессии обнажаются погребенные органогенные отложения мощностью до $130 \mathrm{~cm}$. По спорово-пыльцевым данным отложения относятся к VI и V фазам развития лесов (Кессел, 1963б). В верхней части разреза обнаружен большой кусок древесины, абсолютный возраст которой $6710 \pm 110$ лет (таблица, п. 18).

В $35 \kappa м$ южнее г. Пярну, у с. Р анн а м т са, вдоль стенок Тиммканала обнажаются погребенные органогенные отложения мощностью до 35 cм. В нижней части разреза, близ пересечения канала с шоссе Пярну-Рига, в древесном торфе обнаружен пень березы. Верхняя часть разреза представлена глинистым сапропелем с диатомовыми Campylodiscus clypeus Ehr. и Epithemia turgida (Е.) Ktz. (Кессел, 1963б). Из спорово-пыльцевой диаграммы выясняется, что возраст древесного торфа VII и частично VI фаза. Глинистый сапропель в этом же разрезе относится к VI и V фазам развития лесов (Кессел, 1963б). Абсолютный возраст упомянутого пня $7860 \pm 190$ лет (таблица, п. 9).

На правом берегу ручья Вези ку (западная часть о-ва Сааремаа) обнажается погребенный сапропель с прослойками тростникового торфа мощностью 39 cм (рис. 6). Над сапропелем залегают литориновые прибрежные пески и гравий. Спорово-пыльцевым методом анализировался погребенный сапропель из двух находящихся рядом обнажений. Судя по обеим спорово-пыльцевым диаграммам, предполагаемый возраст погребенного сапропеля в Везику - VII и VI фазы развития лесов (рис. 7). Абсолютный возраст самых нижних и самых верхних слоев данного сапропеля соответственно $7960 \pm 80$ и $6350 \pm 80$ лет (таблица, п. 8 и 19).

В 15 км к северо-западу от г. Кингисеппа, в с. К я р л а, под литориновой береговой косой погребены сапропель, древесный и осоково-древесный торф общей мощностью 0,40 см. По спорово-пыльцевым данным сапропель относится к VI фазе, а древесный и осоково-древесный торф- 


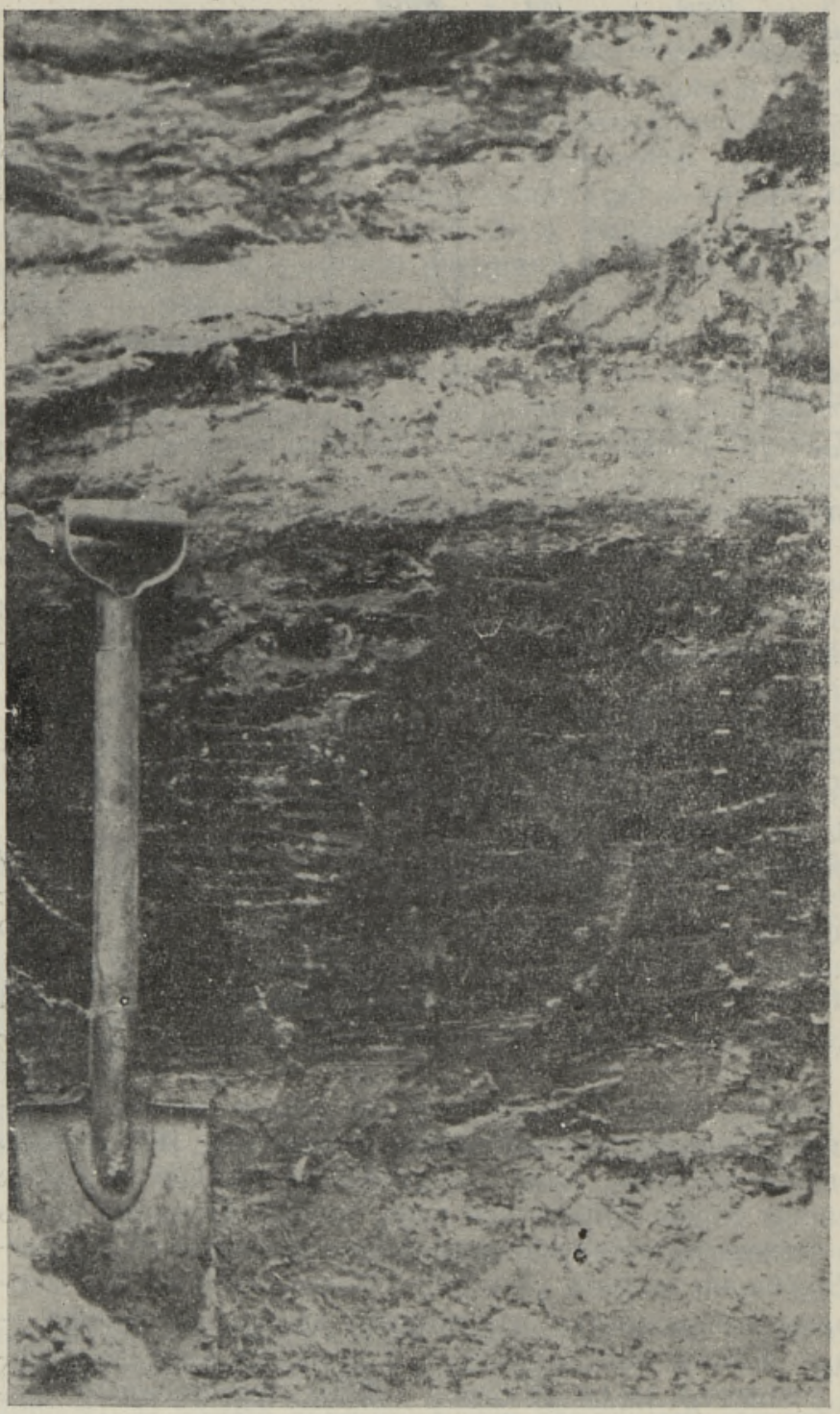

Рис. 6. Погребенный сапропель с прослойками торфа на правом берегу ручья Везику.

к VII фазе развития лесов (рис 8). Абсолютный возраст осоково-древесного торфа и самых верхних слоев сапропеля в Кярла соответственно $7820 \pm 80$ и $7085 \pm 80$ лет (таблица, п. 10 и 14).

Погребенные под литориновыми прибрежными отложениями органогенные осадки были исследованы по $\mathrm{C}^{14}$ еще в местонахождениях В и ra ла и Я ризе. Абсолютный возраст этих погребенных органогенных отложений соответственно $7375 \pm 70$ и $6960 \pm 170$ лет (таблица, п. 13 и 16).

В 12 км к северо-западу от г. Пярну, в с. О а р а, под 2,27-метровыми морскими отложениями Литоринового моря погребен тростниково-осоковый торф с двумя прослойками лагунного сапропеля мощностью 1,33 м. Қак показывает спорово-пыльцевая диаграмма, в сапропеле имеется, к сожалению в небольшом количестве, пыльца широколиственных пород: в нижней части сапропеля до $7 \%$ (Ulmus $4 \%$, Tilia. $2 \%$, 

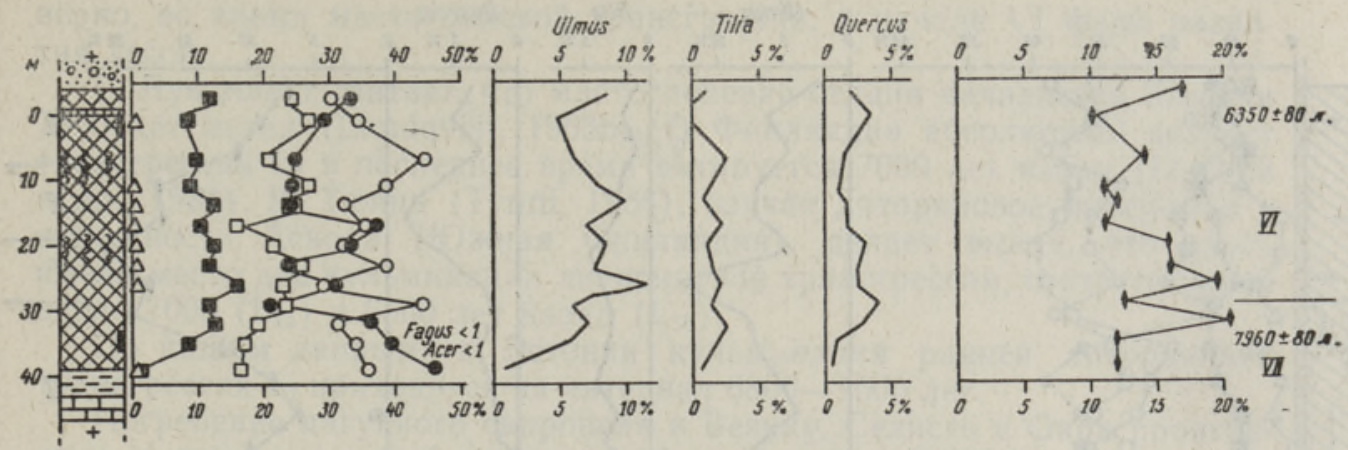

Рис, 7. Спорово-пыльцевая диаграмма местонахождения Везику.

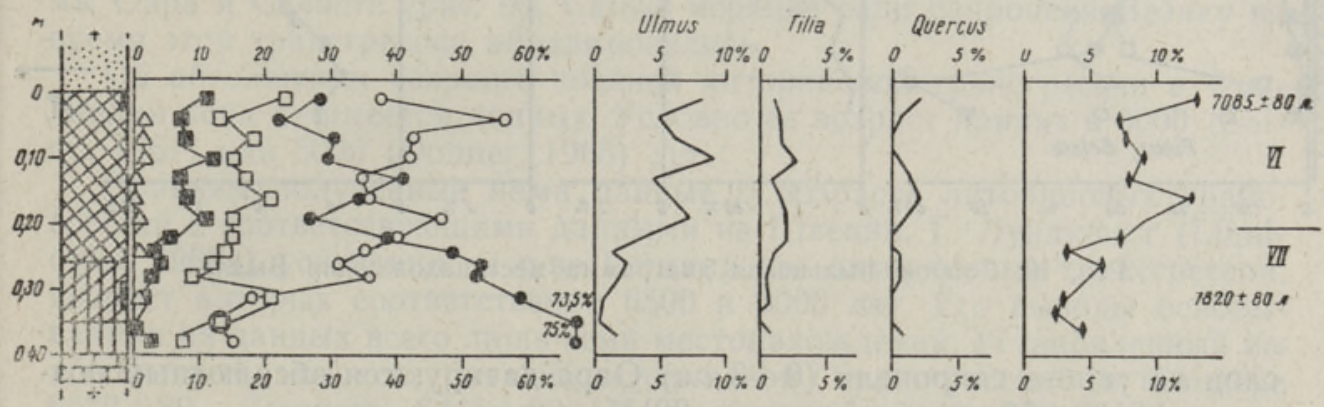

Рис. 8. Спорово-пыльцевая диаграмма местонахождения Кярла.
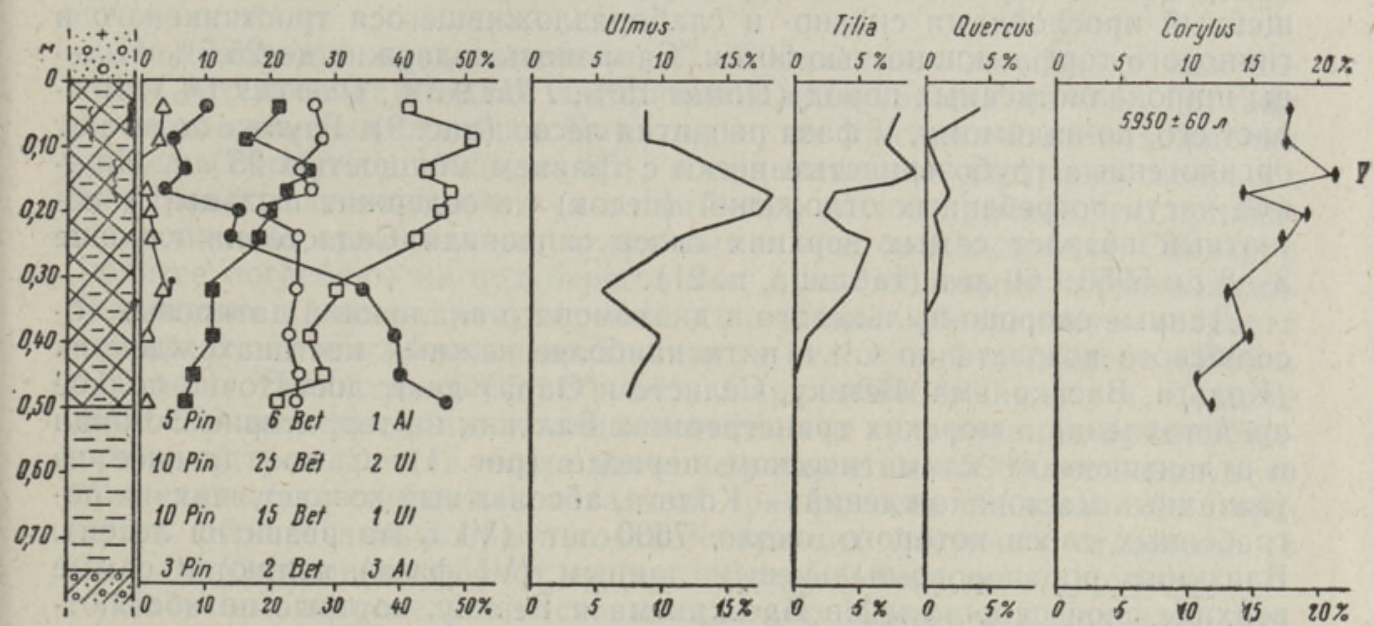

Рис. 9. Спорово-пыльцевая диаграмма местонахождения Селисте.

Quercus 1\%) и в верхней до 14\% (Ulmus 8\%, Tilia 3\%, Quercus 3\%). На основании этих данных верхняя часть погребенных отложений Оара отнесена нами к VI фазе развития лесов. Прослойки лагунного сапропеля (соответственно на глубине 2,30-2,50 и 3,35-3,50 м) содержат остатки солоноватоводных диатомовых водорослей Campylodiscus clypeus Ehr. и Epithemia turgida (E) Ktz., существование которых связывается с ранней и поздней литориновой трансгрессиями. Самые верхние 

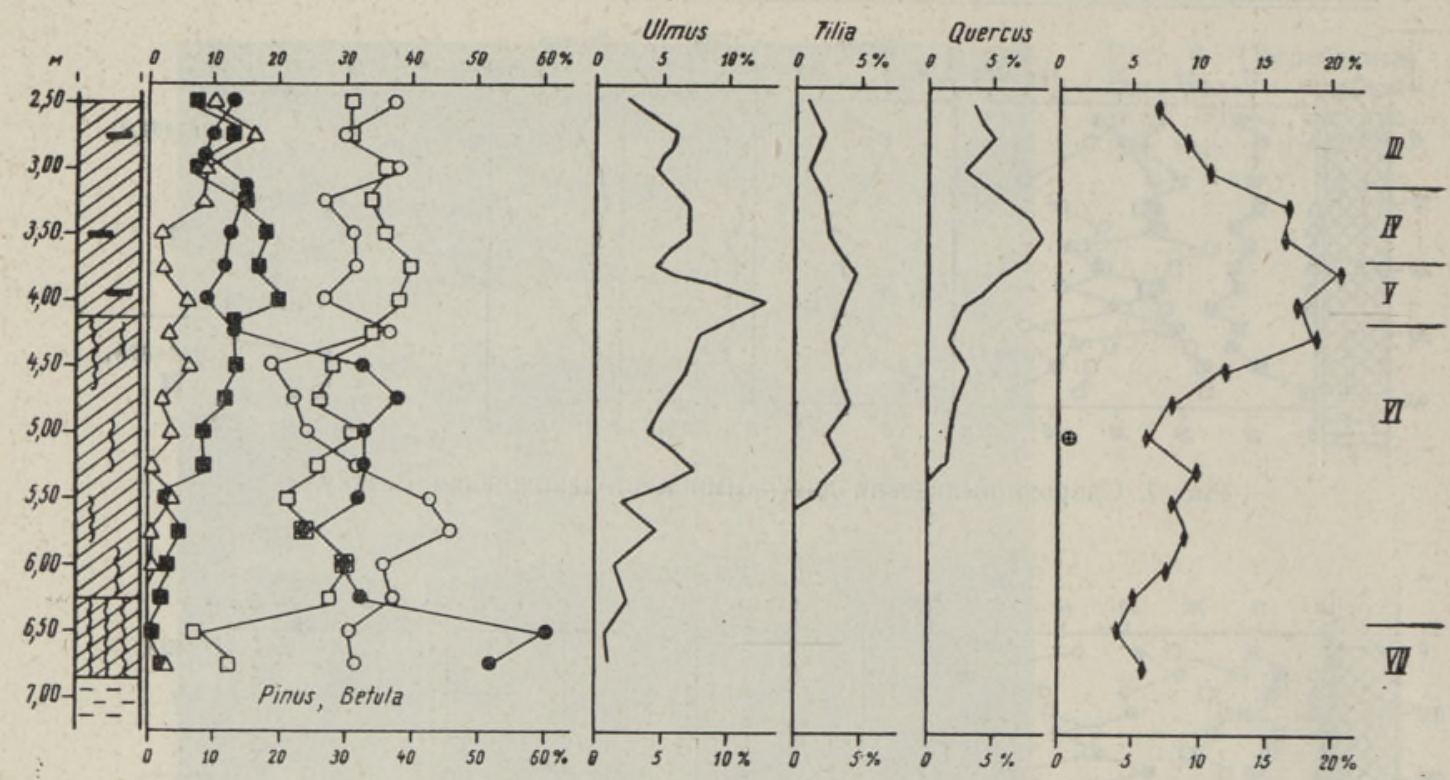

Рис. 10. Спорово-пыльцевая диаграмма местонахождення Вылла.

слои лагунного сапропеля (0-3 cм) Оара датируются абсолютным возрастом $6100 \pm 50$ лет (таблица, п. 20).

В $15 \kappa м$ юго-восточнее местонахождения Кольга, в с. С ел и сте, под литориновым береговым валом погребен глинистый сапропель, обогащенный прослойками сильно- и слаборазложившегося тростникового и гипнового торфа мощностью $50 \mathrm{~cm}$. Сапропель содержит до 25,5\% пыльцы широколиственных пород (Ulmus 15\%, Tilia 9,5\%, Quercus 1\%). Возраст его, по-видимому, V фаза развития лесов (рис. 9). Глубже залегают органогенные грубозернистые пески с гравием мощностью 25 см. Нижняя часть погребенных отложений (песок) не содержит пыльцы. Абсолютный возраст самых верхних слоев сапропеля Селисте на глубине 3-8 см 5950 \pm 60 лет (таблица, п. 21).

Данные спорово-пыльцевого и диатомового анализов и датировки абсолютного возраста по $\mathrm{C}^{14}$ в пяти наиболее важных местонахождениях (Кольга, Васькряэма, Везику, Селисте и Оара) дают достаточно полное прєдставление о морских трансгрессиях Балтики на территории Эстонии в атлантическом климатическом периоде (рис. 1). Самое древнее из указанных местонахождений - Кольга, абсолютный возраст верхних погрєбенных слоев которого около 7500 лет (VI фаза развития лесов). Близкими по спорово-пыльцевым данным (VI фаза) являются самые верхние слои сапропелей в Васькряэма и Везику, которые по абсолютному возрасту (соответственно около 6900 и 6400 лет) отличаются друг от друга примерно на 500 лет. Самыми молодыми (возраст около 6000 лет) оказались верхние слои сапропелей в местонахождениях Селисте и Oapa.

Солоноватоводные и полупресноводные диатомовые водоросли Балтики появляются в погребенных органогенных отложениях разных местонахождений в разное время: в сапропелях Кольга, Васькряэма и Оара соответственно около 7500, 7000 и 6000 лєт назад. Диатомовые водоросли в сапропеле Васькряэма появляются в связи с ранней литориновой трансгрессией $\mathrm{L}_{1}$ в VI фазе развития лесов, а в сапропеле Кольга, на- 
верно, во время мастоглойевой трансгрессии, в начале VI фазы развития лесов.

Г. Лундквист считает, что мастоглойевая стадия началась в Швеции 7500 лет назад (Lundqvist, 1965b). В Финляндии абсолютный возраст трансгрессии $\mathrm{L}_{\mathrm{I}}$ в последнее время датируется 7000 лет назад (Нууррӓ и др., 1964). Р. Тюнни (Туnпi, 1966), изучая литориновое побережье в окрестности Аскола (Южная Финляндия), делает вывод, что здесь имели место две кульминации литориновой трансгрессии, соответственно около $7000\left(\mathrm{~L}_{\mathrm{Ia}}\right)$ и 6500 лет назад $\left(\mathrm{L}_{\mathrm{Ib}}\right)$.

По нашим данным, в Эстонии кульминация ранней литориновой трансгрессии $\mathrm{L}_{\mathrm{I}}$ приходится на интервал 6800 - 7000 лет.

Погребение лагунного сапропеля в Везику, Селисте и Оара происходило в связи с поздней литориновой трансгрессией $\mathrm{L}_{1 \mathrm{I}}$, по-видимому в V фазе развития лесов, как это показывают спорово-пыльцевые диаграммы Оара и Селисте (рис. 9). Самые верхние слои сапропеля Везику во время этой трансгрессии абрадировались.

Об абсолютном возрасте поздней литориновой трансгрессии в Финляндии пока не имеется данных. Условно ее возраст принят в 6000 (Salmi, 1961) нли 5000 (Donner, 1965) лет.

Сравним полученные нами данные о возрасте литориновых трансгрессий с соответствующими данными из Швеции. Г. Лундквист (Lūndqvist, 1965a) установил на о-ве Готланд две литориновые трансгрессии, возраст которых соответственно 6500 и 6000 лет. Его выводы основываются на данных всего лишь семи местонахождений. Установленный им абсолютный возраст ранней литориновой трансгрессии (в Снодере $6630 \pm 80$, Дюниссе $6415 \pm 80$, Мяллингсмюре $6470 \pm 120$ и Хелгмюpe $6450 \pm 100$ лет) достоверен, так как в этих местонахождениях погребенные органогенные отложения покрыты литориновыми береговыми отложениями.

На основании представленного Г. Лундквистом материала нам кажется, что возраст поздней литориновой трансгрессии на о-ве Готланд обоснован еще недостаточно. Как следует из описания местонахождения Снодер (Lundqvist, 1965a, с. 85), в правильности датировки возраста этой трансгрессии сомневается и сам автор по той причине, что проанализированные органогенные отложения в местонахождениях Снодер и Дюниссе погребены не под береговыми, а под эоловыми отложениями. Нам все же кажется, что хорошее совпадение абсолютного возраста верхних слоев погребенных органогенных отложений в Снодере (5995

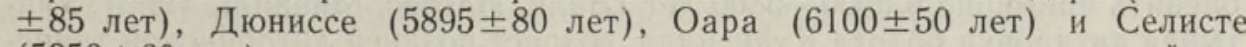
(5950 \pm 60 лет) позволяет условно считать, что кульминация поздней литориновой трансгрессии имела место не раньше чем 5900 лет назад. Для утсчнения абсолютного возраста этой трансгрессии следовало бы определить абсолютный возраст соответствующих лагунных отложений в пределах современных болот, но они в Эстонии пока не обнаружены.

Лагунные сапропели в местонахождениях Кольга и Васькряэма изучены спорово-пыльцевым методом уже пять лет назад и отнесены к VI и V фазам развития лесов (Кессел, 1963a).

В данной статье возраст погребенных органогенных отложений Кольга, Васькряэма, Синди (Кессел, 1963б) и Везику нами переоценен, так как результаты датировок абсолютного возраста по $\mathrm{C}^{14}$ указывают на образование верхних слоев этих отложений не во время V фазы, как предполагалось раньше, а во время VI фазы развития лесов. На пыльцевых диаграммах, характеризующих состав лесов побережья Западной Эстонии, максимум пыльцы широколиственных пород в V фазе развития лесов выявляется сравнительно слабо. Физико-географические условия 
на побережье значительно отличаются от таковых во внутренних районах территории республики и затрудняют интерпретацию пыльцевых диаграмм. В диаграммах погребенных озерных и болотных отложений всегда имеется много пыльцы сосны, ольхи и березы, что обусловлено широким распространением вдоль побережья песчаных грунтов с сосновыми лесами и увлажненных лугов с березовыми и ольховыми рощами. В течение атлантического климатического периода образование озерных и болотных отложений в прибрежной полосе несколько раз прекращалось из-за трансгрессий Балтики и поэтому здесь в большинстве случаев имеются очень тонкие и далеко не полные разрезы органогенных отложений. Определить их возраст по данным спорово-пыльцевого анализа ввиду очень медленного темпа осадконакопления и значительного уплотнения отложений довольно трудно. По абсолютному возрасту верхних и нижних слоев органогенных отложений в Кярла, Васькряэма и Везику можно установить скорость осадконакопления сапропеля, которая составляет в среднем $0,2-0,5$ мм в год.

В последующем сравниваются приведенные нами диаграммы погребенных отложений с пыльцевыми диаграммами близлежащих болотных массивов. С этой целью были составлены диаграммы отложений верховых болот Ряэма и Вылла (п-ов Тыстамаа; рис. 1 и 10). На этих диаграммах максимум широколиственных пород в V фазе развития лесов составляет $20 \%$ (Ulmus $13 \%$, Tilia 5\%, Quercus $2 \%$ ), максимумы пыльцы вяза, липы и дуба четко различимы и последовательность их закономерна. Мсщность болотных отложений в интервале VI-V фаз в Ряэма и Вылла соответственно 1,5 и 2,7 м. Поэтому и спорово-пыльцевая диаграмма их более детальна и обзорна, чем диаграмма близлежащих погребенных отложений Васькряэма, где мощность отложений приблизительно в 5 раз меньше. На основании сравнения диаграмм можно сказать, что выделение VI, V и IV фаз развития лесов в разрезах погребенных отложений является весьма сложной задачей. В них не выявляются с необходимой ясностью или совсем отсутствуют типичные для отдельных фаз атлантического климатического периода черты.

Этим и объясняется несогласие между нашими более ранними интерпретациями (Кессел, 1963б), основанными на определениях абсолютного возраста разреза Куйксилла в Южной Эстонии, и результатами определения абсолютного возраста погребенных органогенных отложений Васькряэма и Везику, приведенными в настоящей статье. Возраст $\mathrm{V}$ фазы развития лесов по данным разреза болота Куйксилла можно оценить примерно в 5000-5800 лет (Валк, Ильвес, Мянниль, 1966). Учитывая датировки болота Куйксилла, возраст поздней литориновой трансгрессии был нами оценен в 5300-5600 лет (Кессел, Раукас, 1967). Новые определения свидетельствуют, что эта оценка была ошибочной, так как для сравнения использовались разные палинологические фазы. Приведенные в данной статье цифры абсолютного возраста верхних частей погребенных органогенных отложений Васькряэма, Кярла и Кольга совпадают с таковыми VII фазы в развитии болота Куйксилла, и только абсолютный возраст верхней части сапропеля Везику соответствует абсслютному возрасту VI фазы в развитии упомянутого болота.

Шведские и финские исследователи доказали, что литориновая стадия синхронна атлантическому климатическому периоду (VI и V фазам развития лесов) (Berglund, 1964; Тynni, 1966 и др.). В соответствующих лагунных отложениях распространяется руководящий комплекс литориновых диатомовых с Campylodiscus clypeus (Sauramo, 1958; Valovirta, 1965). Полученные нами данные хорошо согласуются с этими положениями, так как диатомовая флора с Campylodiscus clypeus появилась в 
латуне Васькряэма около 7000 лет назад, и в то же самое время прекратилось осаждение сапропеля в прибрежном озере Кярла. По нашим спорово-пыльцевым анализам возраст верхних слоев погребенных органогенных отложений Васькряэма и Кярла соответствует раннеатлантическому времени (VI фазе развития лесов).

Имеющийся в нашем распоряжении материал позволяет предполагать, что граница между VII и VI фазами развития лесов на диаграммах Куйксилла и Эндла (Ильвес, Сарв, Валк, 1968) показана неточно и должна быть более древней по сравнению с указанной в данной работе (соответственно $6645 \pm 70$ и $6482 \pm 70$ лет).

Приведенные в настоящей статье датировки абсолютного возраста погребенных органогенных отложений могут быть подразделены на четыре разновозрастные группы, характеризующие континентальные периоды (регрессии водоемов) в прибрежной полосе Северной и Западной Эстонии. Возраст трансгрессии определен на основании наличия перерыва в осадконакоплении озерных и болотных отложений в этой полосе и по датировкам абссолютного возраста погребенных лагунных отложений, содержащих диатомовые водоросли Балтики.

На основании полученных данных на территории Эстонии установлены с начала бореального климатического периода четыре трансгрессивные фазы Балтики (анциловая, мастоглойевая, ранняя и поздняя литориновая). Абсолютный возраст отдельных стадий Балтики мог быть следующий: Анцилового озера 8900-7600, Мастоглойевого моря 7600-7200, раннего Литоринового моря $\left(\mathrm{L}_{\mathrm{I}}\right)$ 7200-6200 лет и позднего Литоринового моря $\left(\mathrm{L}_{\mathrm{II}}\right)$ начиная с 6200 лет.

Исходя из палинологических и геолого-геоморфологических данных и датировок по $\mathrm{C}^{14}$ абсолютного возраста погребенных органогенных отложений Кярла и Везику, можно предполагать, что уровень воды Балтийского моря во время анциловой регрессии в VII фазе развития лесов понизился сравнительно быстро. В окрестностях Кярла и Везкку максимальный уровень Анцилового озера находился на абсолютной высоте около 32 м. Осадконакопление органогенных отложений в указанных местонахождениях, абсолютная высота которых около 15 м, началось 7800--8000 лет назад.

Авторы выражают глубокую благодарность Э. Ильвесу и А. Лийва за определение абсолютного возраста части исследуемого материала, M. Порк за проведение диатомового анализа и Х. Каяк, Г. Эльтерманну и Х. Стумбуру за предоставление геологических материалов.

\section{ЛИТЕРАТУРА}

В а лк У. А., И ль в е с Э. О., М янн и ль Р. П. 1966. Датирование фаз развития лесов по $\mathrm{C}^{14}$ по материалам болога Куйксилла Южной Эстонии. В сб.: Палинология в геологических исследованиях Прибалтики. Рига.

И льв е с Э., С а р в А., В а л к У. 1968. Датирование фаз голоценовых лесов методом $\mathrm{C}^{14}$ по материалу болота Теосааре (Средняя Эстония). Изв. АН ЭССР, Физ. Матем., 17, № 1 .

Л и й в а А., И льв в е Э., П уннин г Я.-М. 1966. Список радиоуглеродных датировок Института зоологии и ботаники Академии наук Эстонской ССР. Изв. АН ЭССР, Сер. биол., 14, № 1 .

Кессел Х. Я. 1963а. Возраст трансгрессий голоценовых бассейнсв Балтики в Эстонии по палинологическим данным. Baltica, 1. Вильнюс.

Кессел Х. Я. 1963б. Голоценовые береговые образования на юго-западном побережье Эстонии. Тр. Ин-та геол. АН ЭССР, ХІІ. Таллин. 
Кессел Х. Я., Р а ук а с А. В. 1967. Прибрежные отложения Анцилового озера и Лнториновсго моря в Эстонин. Ин-т геол. АН ЭССР. Таллин.

Пуннинг Я.-М., Ильв ес Э., Лй й а А. 1966а. Датирование древних образцов радиоуглеродным методом. Изв. АН ЭССР, Сер. биол., 14, № 4.

Пуннинг Я.-М., Лийв а А., Ильвес Э. 1966б. Усовершенствованная методика определения абсолютного возраста по природному радиоуглероду. Изв. АН ЭССР, Сер. физ.-матем. и техн наук, 15, № 2.

B e r g l und B. E. 1964. The Post-Glacial shore displacement in eastern Blekinge, southeastern Sweden. Sver. Geol. Unders., Ser, C., Nr. 599.

D on ne r J. J. 1965. The Quaternary of Finland. The Quaternary, 1. New York-London - Sydney.

H y ур pä E., To i vone n A. V. P., I s o l a A. 1964. Geological Survey of Finland radiocarbon measurements, 3 . Radiocarbon, 6 .

L un d q vist G. 1965a C ${ }^{14}$-dateringar från Gotland. Sver. Geol. Unders., Ser. C., Nr. 602.

L undqvist G. 1965b. The Quaternary of Sweden. The Quaternary, 1. New York-London-Sydney.

Nilss on T. 1935. Die pollenanalytische Zonengliederung der spät- und postglazialen Bildungen Schonens. Geol. Fören. Förhandl., Bd. 57.

S a $1 \mathrm{mi} \mathrm{M.} \mathrm{1961.} \mathrm{Two} \mathrm{Littorina} \mathrm{transgressions} \mathrm{in} \mathrm{Virolahti,} \mathrm{southeastern} \mathrm{Finland.} \mathrm{Bull.}$ Comm. géol. Finlande, No. 196.

S a u r a mo M. 1958. Die Geschichte der Ostsee. Ann. Acad.-Scient. Fennicae. Sarja A. III. Geologica-Geographica, 51.

T y n n i R. 1966. Ober spät- und postglaziale Uferverschiebung in der Gegend von Askola, Südfinnland. Bull. Comm. géol. Finlande, No. 223.

V a lovirta V. 1965. Zur spätquartären Entwicklung Südost-Finnlands. Bull. Comm. géol. Finlande, No. 220.

\author{
Ннститут геологии \\ Академии наук Эстонской ССР \\ Управление геологии СМ ЭССР
}

Поступила в редакцию

$25 /$ XI 1968

\title{
H. KESSEL, J.M. PUNNING
}

\section{LAANEMERE HOLOTSEENSETE TRANSGRESSIOONIDE ABSOLUUTSEST VANUSEST EESTIS}

Ehheneismere, Antsülusjärve ja Litoriinamere rannasetete alla mattunud organogeensete setete (turba, jütja, puidujäänuste) vanuse määramiseks Eestis uuriti palünoloogilisel (H. Kessel) ja radioaktiivse süsiniku meetodil (J.-M. Punning) 15 leiukohast vōetud proove (joon. 1). Tulemused on esitatud tabelis.

Boreaalse kliimaperioodi esimesel poolel (VIII metsade arenemise faasil; Nilsson, 1935) esines Eestis kaks transgressiooni. Nende kulminatsioonid olid ehheneisi, s. o. $9000-9200$, ja antsüluse staadiumil, s. o. 8200-8400 aastat tagasi. Lemmeoja ōietolmudiagrammis (joon. 2) leidub rikkalikult männi õietolmu, kase õietolm aga domineerib Kahala diagrammis (joon. 3 ).

Boreaalse kliimaperioodi teisel poolel (VII faasil) esines Eestis lühikest aega antsüluse regressioon. Kärla (joon. 8) ja Vesiku (joon. 7) leiukohtade ümbruses alanes antsüluse maksimaalne veetase 200 aasta jooksul 15 meetrit.

Kolga leiukoha materjalide pōhjal (joon. 4) esines Mastogloiamere transgressioon VI metsade arenemise faasil, s. o. 7500 aastat tagasi.

Atlantilisel kliimaperioodil esines veel kaks Litoriinamere transgressiooni. Vaskrääma (joon. 5) ja Kärla (joon. 8) leiukohtade materjalide pōhjal oli litoriina varasema transgressiooni $\left(\mathrm{L}_{\mathrm{I}}\right)$ kulminatsioon $6800-7000$ astat tagasi. Litoriina hilisema transgressiooni ( $\left.\mathrm{L}_{11}\right)$ kulminatsiooni vanust ei ole täpselt kindlaks tehtud.

Eesti litoriina transgressioonivöötme kõige ülemisel piiril esinevate mattunud organogeensete setete õietolmudiagrammidel on atlantiline iseloom. Kolga ja Vaskrääma mattunud organogeensete setete ülemised, V metsade arenemise faasi vanusega kihid (Кессел, 1963а ја 1963б) tuleb nüüd ümber hinnata VI faasi vanusteks. See selgub samas piirkonnas esineva Võlla raba terviklikust ōietolmudiagrammist ja Kolga ning Vaskrääma mattunud organogeensete setete absoluutsete vanuste dateeringutest.

Fröjeli (Lundqvist, 1965a) ja Tapu, Võidu, Lemmeoja mattunud organogeensete setete absoluutsed vanused on omavahel vōrreldavad. Sällmyri ja Malmsi analoogilised, aga 
nooremad setted (Lundqvist, 1965a) vastavad Kahala, Altküla ja Ohtla leiukohtadele. Gotlandi leiukohtade materjalide pōhjal eristab G. Lundqvist (1965a) kaks antsüluse transgressiooni, mis esinesid vastavalt 8500 ja 9000 aastat tagasi. On tōenäoline, et varasem ja hilisem antsüluse transgressioon Gotlandil vastavad ehheneisi ja antsüluse transgressioonile Eestis. Gotlandi ja Lõuna-Soome litoriina varasema transgressiooni absolüutsed vanused erinevad Eesti vastava transgressiooni vanusest 200-300 aasta võrra. Gotlandi litoriina hilisema transgressiooni vanus näib olevat vähe põhjendatud, sest Snoderi ja Dynisse organogeensed setted on mattunud rannikuluidete alla. Snoderi ja Dynisse, Seliste (joon. 9), Oara ja Vesiku (joon. 6) leiukohtade materjalide ja dateeringute hea sobivus lubab siiski arvata, et litoriina hilisema transgressiooni vanus ei ole rohkem kui 5900 aastat.

\section{H. KESSEL, J.-M. PUNNING}

\section{UBER DAS ABSOLUTE ALTER DER HOLOZANEN TRANSGRESSIONEN DER OSTSEE IN ESTLAND}

Das Alter der organogenen Ablagerungen (Torf, Gyttja, Großreste des Holzes), die unter den Küstenablagerungen des Echeneismeeres, Ancylussees und Litorinameeres verschüttet liegen, ist mit Hilfe von Pollenanalysen ( $\mathrm{H}$. Kessel) und Radiokarbondatierungen (J.-M. Punning) an 15 Beobachtungsorten in Estland bestimmt worden (Abb. 1). Die Ergebnisse der Untersuchungen sind in der Tabelle vereinigt.

In der ersten Hälite des Boreals (VIII. Phase; Nilsson, 1935) konstatiert man in Estland zwei Transgressionen der Ostsee. Ihre Kulminationen haben in den Stadien des Echeneismeeres vor 9000-9200 Jahren und des Ancylussees vor 8200-8400 Jahren stattgefunden. Pinus kommt im Pollendiagramm von Lemmeoja (Abb. 2) reichlich vor, Betula spielt eine bedeutende Rolle im Pollendiagramm von Kahala (Abb. 3).

In der zweiten Hälfte des Boreals (VII. Phase) dauerte die Regression des Ancylussees in Estland nicht lange. In der Umgegend der Beobachtungsorte Kärla und Vesiku (Abb. 8 und 7) sank der maximale Wasserspiegel des Ancylussees um etwa 15 Meier.in 200 Jahren.

Auf Grund der Materialien von Kolga (Abb. 4) hat vor etwa 7500 Jahren am Anfang der VI. Phase die Transgression des Mastogloiameeres stattgefunden.

Im Atlantikum gab es in Estland zwei Transgressionen des Litorinameeres. Unsere Materialien aus Vaskrääma (Abb. 5) und Kärla (Abb. 8) zeigen, daB die Kulmination der früheren Transgression des Litorinameeres $\left(L_{1}\right)$ etwa vor 6800-7000 Jahren erfolgte. Das Alter der späteren Transgressionen des Litorinameeres ( $\left.L_{I I}\right)$ können wir nicht genau feststellen.

Die Pollendiagramme der verschütteten organogenen Ablagerungen an den oberen Verbreitungsgrenzen der Transgression des Litorinameeres haben atlantischen Charakter. Das vollstandige Pollendiagramm der Moorablagerungen Vōlla (Abb. 10) aus demse'ben Gebiet und das absolute Alter der verschütteten organogenen Ablagerungen weisen darauf hin, $\mathrm{da} \beta$ die oberen Teile der verschütteten organogenen Ablagerungen von Kolga und Vaskrääma, welche früher zur V. Phase gezähilt wurden (Кессел, 1963a, 1963б), jetzt als VI. Phase zu betrachten sind.

Das Alter des Torfes von Fröjel (Lundqvist, 1965a) läßt sich leicht mit dem Alter der verschütteten organogenen Ablagerungen von Tapu, Võidu und Lemmeoja korrelieren. Das Alter der analogischen, aber jüngeren organogenen Ablagerungen von Sällmyr und Malms entspricht dem Alter der verschütteten organogenen Ablagerungen von Kahala, Altküla und Ohtla. Auf Grund der $\mathrm{C}^{14}$-Datierungen der oben angeführten Beobachtungsorte bezeichnet G. Lundqvist (1965a) zwei Transgressionen des Ancylussees. Wahrscheinlich ist es, daß die frühere und die spätere Transgression des Ancylussees nach Lundqvist der Transgression des Echeneismeeres und Ancylussees in Estland entsprechen.

Das absolute Alter der früheren Transgression des Litorinameeres auf Gotland und in Südfinnland unterscheidet sich vom Alter derselben Transgression in Estland uin 200 bzw. 300 Jahre. Das Alter der späteren Transgression des Litorinameeres auf Gotland ist nicht genügend argumentiert. Die untersuchten organogenen Ablagerungen von Snoder und Dynisse sind von Küstendünen verschüttet. Es scheint uns doch, daß auf Grund des guten Zusammenhangs der Materialien und des absoluten Alters der verschütteten organogenen Ablagerungen von Snoder, Dynisse, Seliste (Abb. 9), Oara und Vesiku (Abb. 6), das absolute Alter der späteren Transgression des Litorinameeres nicht mehr als 5900 Jahre betragen dürite. 